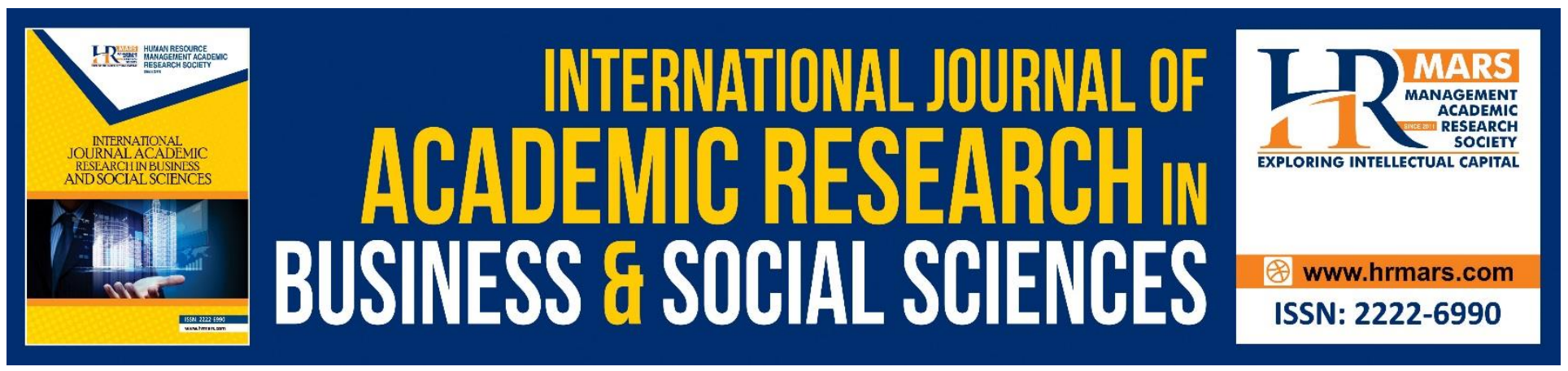

\title{
A Brief Review of the History and Philosophy of Instrument Development in the Social Sciences
}

Khairun Nisa Khairuddin, Zoharah Omar, Steven Eric Krauss, Ismi Arif Ismail

To Link this Article: http://dx.doi.org/10.6007/IJARBSS/v8-i9/4861

DOI: $\quad 10.6007 /$ IJARBSS/v8-i9/4861

Received: 19 August 2018, Revised: 09 Sept 2018, Accepted: 29 Sept 2018

Published Online: 19 October 2018

In-Text Citation: (Khairuddin, Omar, Krauss, \& Ismail, 2018)

To Cite this Article: Khairuddin, K. N., Omar, Z., Krauss, S. E., \& Ismail, I. A. (2018). A Brief Review of the History and Philosophy of Instrument Development in the Social Sciences. International Journal of Academic Research in Business and Social Sciences, 8(9), 1517-1524.

Copyright: (C) 2018 The Author(s)

Published by Human Resource Management Academic Research Society (www.hrmars.com)

This article is published under the Creative Commons Attribution (CC BY 4.0) license. Anyone may reproduce, distribute, translate and create derivative works of this article (for both commercial and non-commercial purposes), subject to full attribution to the original publication and authors. The full terms of this license may be seen

at: http://creativecommons.org/licences/by/4.0/legalcode

Vol. 8, No. 9, September 2018, Pg. 1517 - 1524

http://hrmars.com/index.php/pages/detail/IJARBSS

JOURNAL HOMEPAGE

Full Terms \& Conditions of access and use can be found at http://hrmars.com/index.php/pages/detail/publication-ethics 


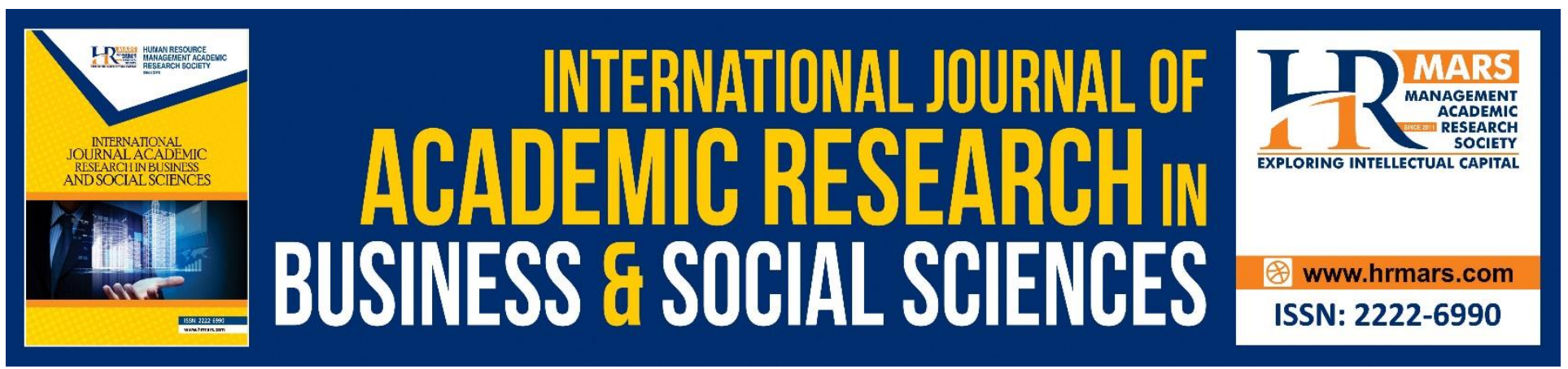

\title{
A Brief Review of the History and Philosophy of Instrument Development in the Social Sciences
}

\section{Khairun Nisa Khairuddin, Zoharah Omar, Steven Eric Krauss, Ismi Arif Ismail}

Department of Professional Development and Continuing Education, Faculty of Educational Studies, Universiti Putra Malaysia, Malaysia

\begin{abstract}
Instrumentation is the heart of research, with almost all empirical research being heavily dependent upon this aspect. The term is also used interchangeably with other terminologies including measurement, scale, questionnaire and inventory. Despite their ubiquitous usage in the scientific literature, it remains unclear as to whether these terminologies pose the same meaning. Therefore, an enhanced understanding regarding instrument development in the social sciences field is contingent upon a grasp of its history and importance. This paper consists of three parts that expound on: (1) the definition of terms related to an instrument, (2) the history and prominent scholars of instrument development in the social science, and (3) the importance of social science instrumentation. Several academic journals have served as a reference, accompanied by books, reports and online encyclopaedia in ensuring a comprehensive review of the history of instrumentations in the social sciences.
\end{abstract}

Keywords: Instrument Development, Measurement, Questionnaire, Scale, Social Science

\section{Introduction}

Instrumentation is the heart of a research; almost all empirical research depends heavily on it (Goldstein, 2012). The field of social science is perceived to be challenging as researchers exert abundant efforts to measure the latent variables of a phenomenon. These latent variables are variables that are not directly observed, hence making it difficult to study the phenomenon. To overcome this, social scientists develop instruments by generating items which consist of several statements to measure the phenomenon often in the forms of questionnaires. Instrument such as questionnaires are the most frequently used form of data collection in social research. They are tremendously powerful instruments when properly constructed.

Nowadays, instruments are also required in identifying organizational problems and the best possible solution. Thus, the introduction of new instruments is pertinent. Although instruments to measure a certain phenomenon in the field of social science are already developed, these instruments may not be suitable in different context or countries with different cultures and practices 
(Cohen \& Swerdik, 2009). Hence, an extension of existing ones is paramount to social scientists' effort, especially during the process of instrument development. The development of a good instrument is a process that requires conceptualization, generation of items, and consideration in terms of sequences of items and suitability of words and length.

Instrument, measurement, scale, questionnaire and inventory are some of the terminologies that have been used to measure a concept or phenomenon, especially in quantitative research. Spanning several decades of application, their usage has been utilized interchangeably by scholars and researchers referring to a tool to measure something. However, questions arise regarding whether these terms pose the same meaning and whether all latent variables are measurable. It begs the purpose of 'measurement' and its actual necessity.

Therefore, this paper aims to answer these questions so as to provide a better understanding of the importance of instrument development in social science. In order to enhance such knowledge, a basic background on the history and philosophy behind the meaning of instrument in social science is called for. This paper is sectioned into three parts discussing about: (1) the definition of terms related to instrument, $(2)$ the history and prominent scholars of instrument development in social science, and (3) the importance of instrument. The methodology behind its preparation is mainly via reviewing academic journals in Social Science, books and reports on instrument development, as well as the Britannica Online Encyclopaedia of classic scholar's biography.

\section{Definition of Terms}

In social science, many terms have been used to describe measurement tools, with words like instrument, scale, and questionnaire being commonly used by scholars and researchers. Meanwhile, others may opt for more sophisticated terms, such as inventory. The terms have also been commonly used interchangeably when discussing about instrument development. This poses the question whether these terms have similar meanings or distinct. Table 1 below presents the definition and short explanations for each of these terms.

Table 1. Definitions of terms

\begin{tabular}{|l|l|}
\hline \multicolumn{1}{|c|}{ Terms } & \multicolumn{1}{c|}{ Definitions } \\
\hline Measurement & $\begin{array}{l}\text { "Measurement is the assignment of numerals to objects or events according to rules" } \\
\text { (Stevens, 1946, p.677) }\end{array}$ \\
\hline Instrument & $\begin{array}{l}\text { "Instrumentation refers to the tools or means by which investigators attempt to measure } \\
\text { variables or items of interest in data collection process" (Hsu \& Sandford, 2012, p.608) }\end{array}$ \\
\hline Scale & $\begin{array}{l}\text { "Collections of items combined into a composite score and intended to reveal levels of } \\
\text { theoretical variables not readily observable by direct means" (DeVellis, 2012, p.11) }\end{array}$ \\
\hline Questionnaire & $\begin{array}{l}\text { "Questionnaire is a set of standardized questions, often called items, which follow a fixed } \\
\text { scheme in order to collect individual data about one or more specific topics" (Trobia, 2011, } \\
\text { p.653) }\end{array}$ \\
\hline Inventory & $\begin{array}{l}\text { "Inventory can be described as a list of traits, preferences, attitudes, or abilities used to } \\
\text { evaluate personal characteristics or skills" (Merriam-Webster). }\end{array}$ \\
\hline Psychometrics & "Any branch of psychology concerned with psychological measurements" (WordNet) \\
\hline Test battery & $\begin{array}{l}\text { "A set or series or correlated presumptions delivered at one time, with scores documented } \\
\text { separately or mixed to produce a single score" (Nugent, 2013) }\end{array}$ \\
\hline
\end{tabular}


Based on these definitions, it can be posited that measurement, instrument, questionnaire, inventory, and psychometrics are terms that refer to the same meaning: a tool for measuring a concept. Nevertheless, their suitability for usage in a study is reliant upon the purpose of the study itself and the phenomenon to be measured. Examples of the terms used in the title of instruments in the social sciences such as Barrera Social Support Scale (BSSS; Barrera, Chassin \& Rogosch, 1993); Newcomb Loneliness and Support Inventory (NLSI; Newcomb \& Bentler, 1986); My Family and Friends Measure (MFF; Reid, Landesman, Treder \& Jaccard, 1989); Survey of Children's Social Support (SCCS; Dubow \& Ullman, 1989); and Armed Services Vocational Aptitude Battery (ASVAB).

\section{History of Instrument Development in Social Science}

George W. Bohrnstedt has provided a short history and review of measurement in social science during 'The Importance of Common Metrics for Advancing Social Science Theory and Research' workshop held at Washington D. C. in 2010 (see National Research Council, 2011). The senior vice president for social emeritus at the American Institutes for Research has declared then that social science measurement was kick-started by Pierre Guillaume Frédéric Le Play (1806-1882).

In contrast, Duncan (1984) mentions in his book 'Notes on Social Measurement: Historical and Critical' that Francis Galton pioneered psychometrics development while testing individual differences in terms of ability and mental processes. Developments in the field of psychometrics were popularised around the turn of the $20^{\text {th }}$ century. It has since been extended from psychological testing to the measurement of personality traits, interest, values, and attitudes (Duncan, 1984). After World War II, social researchers have directed their attention to test score usage in investigations on educational opportunity, social mobility, and achievement of occupational and economic status.

\section{Significant Events in the Timeline of Instrument Development in Social Science}

Jones and Thissen (2007) reviewed the history of psychometrics and elucidated the information in a concise article. The following section has presented significant events as per extracted from their article, with some additional information gathered from various other resources. 
INTERNATIONAL JOURNAL OF ACADEMIC RESEARCH IN BUSINESS AND SOCIAL SCIENCES Vol. 8, No. 9, Sept. 2018, E-ISSN: 2222-6990 @ 2018 HRMARS

Table 2. Significant Events in the History of Instrument Development

\begin{tabular}{|c|c|}
\hline Years & Significant Events \\
\hline 1905 & $\begin{array}{l}\text { Alfred Binet and Theophile Simon (French psychologists) introduced a test for measuring intelligence } \\
\text { among children. Known as the Binet-Simon scale, it has been used to identify learning difficulties. The } \\
\text { introduction of intelligence testing has subsequently boosted intellectual discussions among scholars } \\
\text { in Great Britain and the U.S. }\end{array}$ \\
\hline 1917 & $\begin{array}{l}\text { Robert Yerkes (American psychologist) was appointed as the President of the American Psychologist } \\
\text { Association (APA). He developed an intelligence test for military recruitment during the First World } \\
\text { War. The tests were utilized extensively during that period. Other influential scholars like Edward } \\
\text { Thorndike, Arthur Otis and Louis Leon Thurstone also promoted Yerkes' work. They were American } \\
\text { psychologists revered for their work in the same field, which resulted in the establishment of a School } \\
\text { for Military Psychology at Camp Oglethorpe, Georgia and the development of psychological testing for } \\
\text { U.S. army recruits. }\end{array}$ \\
\hline 1921 & $\begin{array}{l}\text { Early works on psychophysics, correlation, and ability testing were produced by Brown and Thomson } \\
\text { (British psychologists). Significant contributions were made in the development of test theory and } \\
\text { factor analysis respectively. }\end{array}$ \\
\hline 1935 & $\begin{array}{l}\text { Thurstone (American psychologist) together with his colleagues and graduate students had founded } \\
\text { The Psychometric Society. The first volume of their journal Psychometrika, which was sponsored by } \\
\text { the society was published in March } 1936 \text {. }\end{array}$ \\
\hline 1936 & $\begin{array}{l}\text { Guildford (American psychologist) published the first edition of Psychometric Methods. This work } \\
\text { emerged as the standard college text for those studying psychological measurement at the time. }\end{array}$ \\
\hline 1941 & The Journal of Educational and Psychological Measurement was published. \\
\hline 1964 & $\begin{array}{l}\text { The National Council on Measurement in Education published articles on psychometrics application } \\
\text { towards measurement in an educational setting in the Journal of Educational Measurement. }\end{array}$ \\
\hline
\end{tabular}

Based on the historical events presented in Table 2 above, psychological instrument has emerged in the early twentieth century in measuring human intelligence, specifically among children. Then, it has been extended towards military recruitment during the First World War. The importance of psychometrics has become a central discussion among classic scholars in the twentieth century, spurring many journals related to psychometric research to be published. They include the Applied Psychological Measurement, Behaviormetrics, Psychological Methods and more in the 1960's. Hence, psychometrics usage has become widely utilized everywhere until today, especially in the educational settings and social science research.

\section{Prominent Scholars of Instrument Development}

Many influential scholars have greatly contributed to the history of instrument development in the field of social science, such as Francis Galton, James McKeen Cattell, and Charles Edward Spearman. In this section, the bibliography of these selected scholars has been reviewed as per Britannica Online Encyclopaedia and subsequently presented below.

\section{Sir Francis Galton}

Sir Francis Galton was born on 16 February 1822 in Birmingham, England and died on 17 January 1911. As a cousin of Charles Darwin, Galton was known as the pioneer in the studies of human intelligence, with his significant contributions as a statistician who had invented correlation and regression analysis. He was regarded as the Father of Psychometric. During his life, Galton had written 9 books and 200 papers related to various diverse subjects; his fundamental interest was in human 
INTERNATIONAL JOURNAL OF ACADEMIC RESEARCH IN BUSINESS AND SOCIAL SCIENCES

Vol. 8, No. 9, Sept. 2018, E-ISSN: 2222-6990 @ 2018 HRMARS

eugenics, but he had also shown concern in improving the standards of measurement. Jones and Thissen (2007) in particular have credited Galton as a champion of the measurement of individual differences.

\section{James McKeen Cattell}

James McKeen Cattell was born on 25 May 1860 in Easton, Pennsylvania, United States. According to Pillsbury (1947) in the Biographical Memoir of James McKeen Cattell 1860-1944, Cattell had been a dominant factor in the introduction of experimental technique in America. His works as a psychologist have also contributed to the field and destinies of psychology for generations of scholars. He developed one of the first laboratories in America. Cattell had similar interests with Galton in studying individual differences, spending time in Galton's laboratory in London during the late 1880s to develop psychometric measures (Jones \& Thissen, 2007). His return to the United States has been marked with the achievement of a professorship in psychology at the University of Pennsylvania in 1887 (Pillsbury, 1947). Much of his work in studying individual differences have been greatly influenced by methods and ideas from Francis Galton. Furthermore, he was also very active in many organizations, such as being one of the founders of APA in 1892 and later serving as the president in 1895. One of the Cattell's achievements in developing psychometrics was documented in the "Physical and Mental Measurements of Columbia University Students" in 1896. He died on 20 January 1944 in Lancaster, Pennsylvania, United States.

\section{Charles Edward Spearman}

Charles Edward Spearman, also known as Spearman was another British psychologist that had been greatly influenced by Galton. Born on 10 September 1863 in London, he had theorized a general factor of intelligence, $\mathrm{g}$. He had also significantly contributed to statistics by pioneering the statistical technique called factor analysis and has also been known as the father of classical test theory (Jensen, 1994). Furthermore, Spearman is also famous for a rank correlation measure named as SpearmanRho Correlation (Lovie \& Lovie, 1996). He had served as an officer in the British army (1883-1897) prior to realizing his interest in psychology and pursued his Ph.D. with Wilhelm Wundt at the University of Leipzig. His academic career at University College, London had started in 1907 and he proceeded to become a professor from 1911 to 1931 . He died on 17 September 1945 at the age of 82 years old.

\section{Importance of Instrument Development}

In order to develop an instrument, common concepts and valid constructs are required, with the supplementation of strong theories. Bohrnstedt (2010) has inferred that a problem in social science arises when there is the lack of strong theories, but social scientists still proceed with their efforts on developing instruments, which is reflected in the dearth of well-accepted instruments. Bohrnstedt (2010) has also pointed out that "good theory and good measurement are often prerequisites for a standardized measure". A concept is usually based on a theory; developing an instrument requires a solid theory that is widely accepted in the scientific community. Therefore, the ability to develop a measurement is dependent on the state of theory. 
INTERNATIONAL JOURNAL OF ACADEMIC RESEARCH IN BUSINESS AND SOCIAL SCIENCES Vol. 8, No. 9, Sept. 2018, E-ISSN: 2222-6990 @ 2018 HRMARS

As social science consists of various disciplines, common concepts and constructs are measured differently according to each discipline. Thus, it is important to learn how each discipline uses different terms and interpreting their meanings responsibly. However, one should bear in mind that changing times and situations will inevitably transform concepts and what the society regards as important. The recent years have displayed greater interest among social scientists in measuring less tangible concepts, such as subjective well-being, satisfaction, and social connectedness. As the social perception of the concept has probably evolved compared to 10-20 years ago, so measures will also need to be modified accordingly.

This article has utilized the metaphor 'heart' to express the importance of an instrument in a research. A dysfunctional heart will affect the entire body; in a research, an unjust measurement will render the whole research useless. The subsequent impact will not only be felt by the researchers, as the society will also be affected by the wrong measurements and the resulting inappropriate suggestions and erroneous interventions. Therefore, a good social scientist should always be very careful and vigilant either in adopting or developing an instrument for a research.

\section{Acknowledgement}

The authors would like to acknowledge Universiti Putra Malaysia for the financial funding of this study under the grant of Geran Inisiatif Putra Siswazah (GP-IPS/2018/9609300).

\section{Corresponding Author}

Khairun Nisa Khairuddin can be contacted at khairunnisabintikhairuddin@gmail.com

\section{References}

Alfred Binet Early Life and Education: Contributions and Achievements. (2018). Retrieved July 3, 2018, from https://www.famousscientists.org/alfred-binet/

Barerra, M. Jr., Chassin, L., \& Rogosch, F. (1993). Effects of social support and conflict on adolescent children. Journal of Personality and Social Psychology, 64, 602-612.

Cohen, R. J., \& Swerdik, M. E. (2009). Psychological Testing and Assessment: An Introduction to Tests and Measurement. McGrawHill (7th Ed.). United States of America: McGraw-Hill Primis.

DeVellis, R. F. (2012). Scale Development: Theory and Applications. SAGE publication Ltd (Third Ed). Thousand Oaks: SAGE Publications, Inc.

Dubow, E. F, \& Ullman, D. G. (1989). Assessing social support in elementary school children: The survey of children's social support. Journal of Clinical Child Psychology, 18, 52-64.

Duncan, D. O. (1984). Notes on Social Measurement: Historical \& Critical. United States of America: Russell Sage Foundation.

Goldstein, H. (2012). Francis Galton, measurement, psychometrics and social progress. Assessment in Education: Principles, Policy \& Practice, 19(2), 147-158.

https://doi.org/10.1080/0969594X.2011.614220

Hsu, C. C., \& Sandford, B. A. (2012). Instrumentation. In N. J. Salkind (Ed.), Encyclopedia of Research Design (pp. 608-610). Thousand Oaks: SAGE Publications, Inc. https://doi.org/10.4135/9781412961288

Jones, L. V., \& Thissen, D. (2007). A History and Overview of Psychometrics. Handbook of Statistics, 
INTERNATIONAL JOURNAL OF ACADEMIC RESEARCH IN BUSINESS AND SOCIAL SCIENCES

Vol. 8, No. 9, Sept. 2018, E-ISSN: 2222-6990 (C) 2018 HRMARS

26, 1-27. https://doi.org/10.1016/S0169-7161(06)26001-2

Lovie, P., \& Lovie, A. D. (1996). Charles Edward Spearman, F.R.S. (1863-1945). Notes and Records of the Royal Society of London, 50(1), 75-88. https://doi.org/http://www.jstor.org/stable/531842

National Research Council. (2011). The Importance of Common Metrics for Advancing Social Science Theory and Research : A Workshop Summary. (R. M. Li, Ed.), The National Academies Press. Washington, D.C.: The National Academies Press. Retrieved from www.nap.edu

Newcomb, M. D., \& Bentler, P. M. (1986). Loneliness and social support: A confirmatory hierarchical analysis. Personality and Social Psychology Bulletin, 12, 520-535.

Nugent, Pam M. S., (2013). “Test Battery”, in Psychology Dictionary.org. Retrieved July 20, 2018, from https://psychologydictionary.org/test-battery/

Pillsbury, W. B. (1947). Biographical Memoir of James McKeen Cattell 1860-1944. National Academy of Sciences (Vol. 25). https://doi.org/10.1037/h0063297

Reid, M., Landesman, S., Treder, R., \& Jaccard, J. (1989). "My family and friends": Six- to twelveyear-old children's perceptions of social support. Child Development, 60, 896-910.

Stevens, S. S. (1946). On the Theory of Scales of Measurement. Science, 103(2684), 677-680. https://doi.org/10.1126/science.103.2684.677

The Editors of Encyclopedia Britannica. (2018). Charles E. Spearman. Retrieved July 18, 2018, from https://www.britannica.com/biography/Charles-E-Spearman

The Editors of Encyclopedia Britannica. (2018). James McKeen Cattell. Retrieved July 18, 2018, from https://www.britannica.com/biography/James-McKeen-Cattell

The Editors of Encyclopedia Britannica. (2018). Sir Francis Galton. Retrieved July 18, 2018, from https://www.britannica.com/biography/Francis-Galton

Trobia, A. (2011). Questionnaire. In P. J. Lavrakas (Ed.), Encyclopedia of Survey Research Methods (pp. 653-655). Thousand Oaks: SAGE Publications, Inc.

https://doi.org/10.4135/9781412963947 